8 
A number of the officials of the national government under President Buchanan, the Postmasters at Ft. Dodge, Iowa City and West Point, and the Receiver of Public Monies at Decorah, were adjudged in default in their accounts and judgments against them and their bondsmen for serious sums were entered on the record. Among the important civil suits decided were, J. Edgar Thompson vs. the County of Lee, and Rogers vs. the City of Burlington, in which Judge Miller held certain issues of bonds in aid of railroads invalid; concurring therein in the holding of the Supreme Count of Iowa. In Walkley vs. the City of Burlington, in which the plaintiff sought to mandamus the city council to appropriate monies to pay a judgment, he granted an altemative writ allowing the eity until the next term of court to show cause why such a writ should not issue. Another interesting case was Jacob Edivards, et al., vs. Addison Daniels, et al., in which a plea of usury was set up in defense against an attachment issued to realize on promissory notes. Judge Miller held that where notes made in Iowa, payable in Boston, are usurious by the laws of both states, the effect will be governed by the laws of Iowa; whereas in the case of notes made in Boston and payable in Boston the full amount specified on the face of the notes may be received; the court in the latter case would not enforce the penal law of usury of Massachusetts. ${ }^{\circ}$ In the two cases last mentioned, Mr. S. V. White, for forty years past a notable figure in Wall Street, was one of the attorneys. He was then a resident of Des Moines.

$$
\text { F. I. H. }
$$

- oThe cases mentioned are not reported in Woolworth's Circuit Court Reports-Justice Miller's Decisions. Brief mention of the rulings may be found in the Daily State Register, May 19, 20, 22.

\section{ALEXANDER BROWN, HIS FAMILY AND FRIENDS.}

The life of Alexander Brown, of whom an article by his life-long friend, Hon. Robert Sloan, appears elsewhere in this number of The Annals, is of the type most useful in the early 
stages of the development of a community. The writer was a student under him, and later his law partner, and was brought up among influences of which his life was one of the strongest.

Hugh Brown, the father of Judge Brown, left Scotland and settled in Luzerne county, Pa. His oldest child, a daughter in her teens, remained in Scotland, as was intended temporarily. This temporary arrangement became permanent, and she never afterward saw her parents. She lived to a great age, and died, within two miles of the home of Robert Burns. She maintained an interest and love for her family in America through correspondence. The letters she exchanged with her brother, Judge Brown, whom she never saw, are a most interesting source of information on early emigration. From Pennsylvania, Hugh Brown brought his family to Keosauqua, Van Buren county, Iowa, in 1844. A daughter, Sarah, was married to James Johnston, their only child being the late Captain Benjamin Johnston, who died in the United States service as consul at Ceiba, Honduras. He had served as a Private in Company E, 15th Iowa Regiment Volunteer Infantry, and as First Lieutenant in Company G, 67th U. S. C. Infantry. In 1844 Hugh Brown and James Johnston established the first steam power mill at Keosauqua. It was erected upon ground the title to a part of which was in doubt. They took possession under a quit claim deed executed by ninety citizens of the town, with the understanding that as these were all the freeholders there, no one could possibly make adverse claim. The deed, dated July 21, 1844, now in the collections of the Historical Department of Iowa, bears the autograph signatures of John Fairman, James Hall, Edwin Manning, Meshach Sigler, and other proprietors of the town of Keosauqua, and of no less important men in the political and business world than Richard Humphrey, James B. Howell, Elisha Cutler, Jr., Henry Heffleman, James M. Shepherd, George G. Wright, Andrew J. Davis, Henry H. Barker, James Kinnersly, John McCrary and Charles Baldwin. 
Upon this title, whose value lay perhaps in a moral support rather than on a legal foundation, there was launched an enterprise of large significance, to that place and in that day.

Here as a boy, Judge Brown acquired in mechanics that ingenuity which he exercised in accounts and in the management of men. And in the same enterprise, in different capacities, a training was given to his brother, James Brown, for a long time at the head of the state school for the blind at Vinton, and his brother, John G. Brown, the earliest bank cashier in Van Buren county, having at the time of his death served in the banking house of Edwin Manning almost from its inception. Another brother, Hugh G. Brown, who enlisted in Company $\mathbf{E}$, Fifteenth Iowa Volunteers, was appointed Second Lieutenant, December 1, 1861; promoted to First Lieutenant, July 9, 1862; aid-de-camp with rank of Captain, August 28, 1863; Brevet Major, September 29, 1864; Brevet Lieutenant Colonel, March 31, 1865; and Major, April 26,1898 . After being mustered out of the volunteer service he entered the regular army as Lieutenant of the Eighteenth Infantry, was transferred first to the Thirty-sixth, then to the Twelfth Infantry. He was four times brevetted for gallant and meritorious service, served for a time in the compilation of the Rebellion Records, and, after service in the SpanishAmerican war in the Philippines, retired May 16, 1899, and died at Keosauqua, November 30, 1901.

A sister, Anna, was married to Dr. William Craig, and was the mother of Lieutenant Collin.P. Craig, who graduated from the United States Naval Academy, and died while in the service with the rank of Lieutenant. Thus may be seen something of the wealth of blood contributed to an Iowa settlement by one Scotch emigrant. The above named members of the family, and many others, lie buried near to each other, the body of Benjamin Johnston only recently having been returned from Ceiba, and interred by the United States Government in the family burial plot. 
Judge Brown's preparation for his life's work was made at a time and under conditions which have more than once been noted in the writings and speeches of pioneer Van Buren county men. In the main, it was in the school of the Rev. Daniel Lane, which flourished during and before the Civil War, and in which were enrolled George W. McCrary Secretary of the Interior; Felix T. Hughes, Railway President; Samuel M. Clark, Editor and Member of Congress; William W. Baldwin, Lawyer and Railway Official; Thomas S. Wright, Railway Attorney; Samuel Elbert, Governor of Colorado; E. K. Valentine, Member of Congress from Nebraska; Edwin $O$. Stannard, Member of Congress, founder and President of the St. Louis Board of Trade. These are merely the names of a few of the most widely known. There were scores of young men and women prepared by Mr. Lane for the professions and active business life.

Judge Brown held the favor of a remarkable number of men who were either in themselves or were by blood or affinity closely related to men of the first importance in Iowa matters, both military and civil.

Judge Sloan has noted the law firms of the Keosauqua bar. The writer draws from notes of conversations with Judge Brown for further facts. There was an interesting relationship of individuals of firms, and of firm with firm, both in the early and more recent times. George G. Wright, besides being a strong and able man, was the brother of Governor Joseph A. Wright of Indiana, who for a time lived at Keosauqua. Rachel, a sister of these brothers, was the wife of Charles Baldwin, of the firm of Wright \& Baldwin, and the mother of a generation of strong men and women, of whom William W. Baldwin of Burlington, Iowa, is the eldest. The sons of Judge Wright have enjoyed the leadership of the bar in Iowa. Another sister of Judge Wright was the mother of two daughters who were married respectively to Hon. Joseph C. Knapp, and Hon. Henry Clay Caldwell, two members of the firm of Knapp, Caldwell \& Wright.. George F. Wright, of the firm was not a relative of George G. Wright, but was the son of a 
half-brother of Joseph C. Knapp. Pursuing the matter further, we find the oldest son of George G. Wright, Thomas S. Wright, chief counsel of the C., R. I. \& P. Ry. at the time of his death, and the oldest son of Charles Baldwin, William W. Baldwin, assistant to the president of the C., B. \& Q. Ry. system at the present time. These two eminent sons of eminent parents married respectively. a sister and a niece of the late Major General James M. Tuttle. All these individuals were born or resided in Van Buren county before or during the Civil War. Mere kinship and nothing else is lacking in the beautiful and deep friendship and esteem always interchanged among themselves by these people, and the family of Edwin Manning. Mr. Manning inclined but slightly toward public life. He was the wealthiest citizen in the State in 1860, and for thirty years thereafter. Domestic life and business shared equally his interest and reflected equally great credit upon him. His house was made even more open to the Wright relationship by reason of its presiding genius, Mrs. Manning, the adopted daughter of Governor Wright. She came to Keosauqua to be mother to Mr. Manning's children of a former marriage in 1842 with Sarah J. Sample of Keokuk, who died in 1857. Mrs. Manning and Mrs. Knapp now reside in the homesteads erected by their distinguished husbands. They are the two resident survivors of that interesting group of pioneers, the others being Judge Henry Clay Caldwell and his wife of Los Angeles.

Judge Brown was never without the complete confidence and esteem of this old group. He was at times in the confidential employ of Edwin Manning, and was always a confidant and advisor of John G. Brown, his brother, whose long service and fidelity was a most important factor in the success of Mr. Manning. In his marriage Judge Brown was allied with a family of equal interest, for his wife was a daughter of Thomas Rankin, an ideal gentleman of the age and school of Charles Baldwin. The mother of Mrs. Brown was a daughter of Chappell Bonner, an intimate friend of the pioneer preacher, Samuel Clark. 
But in his own life Judge Brown exemplified the peculiar value of his type of citizen. Besides the offices and honors mentioned by Judge Sloan, he religiously attended to, and efficiently performed the duties of Mayor of Keosauqua for years, and was a member of the Board of School Trustees continuously for twenty-four years.

This man actually withheld the appearance of suffering from the world, and only his intimates knew he was without freedom from pain ever after receiving his wound at Corinth. With such fortitude, and a genius for selecting the humor in a situation, and for gauging the capacity of his auditor for receiving it, his personality was a prism through which affairs passed into the lives of all he touched, only in such quality and character as were inspiring.

\section{PERMANENT MARKING OF HISTORIC SITES.}

The Iowa Daughters of the American Revolution have under consideration extensive plans for marking Iowa Historic Sites. As yet their services in this respect have been rather as individual chapters, and without special regard for a general state-wide movement. The Historical Department has urged the society to assume responsibility for a general if not uniform method of determining and appropriately marking historic sites, and has advanced through correspondence and public addresses by the Curator some reasons therefor. Responses have been received which give promise that widespread and significant results may be expected during the next year. So much present benefit is derived from the agitation for funds, the gathering of evidence as to sites and importance of events and persons commemorated, in the actual erection and ceremonies connected therewith, and in the positive and permanent influences for good that reside in a visible monument, that we feel very amply warranted in sharing the labor and meeting some expense on the part of the Historical Department. 
Copyright of Annals of Iowa is the property of State of Iowa, by \& through the State Historical Society of Iowa and its content may not be copied or emailed to multiple sites or posted to a listserv without the copyright holder's express written permission. However, users may print, download, or email articles for individual use. 